\title{
THE MODEL OF REGIONAL DEVELOPMENT OF AGRARIAN SCIENCE IN UKRAINE: THE RELATIONSHIP BETWEEN A CENTENARY PAST AND TODAY
}

\author{
Nataliia Kovalenko ${ }^{*}$, Olha Hloba ${ }^{2}$ \\ ${ }^{1 *}$ Institute of History of Agrarian Science, Education and Technique of NSAL NAAS, Ukraine; \\ ${ }^{2}$ Hryhorii Skovoroda University in Pereiaslav, Ukraine; \\ *Corresponding Author Nataliia Kovalenko, e-mail: BoikoNP@ukr.net;
}

Received June 2021; Accepted July 2021; Published September 2021;

DOI: $\underline{\text { https://doi.org/10.31407/ijees11.423 }}$

\begin{abstract}
The article highlights a centenary evolution of the organization of the regional principle of agricultural research as one of the types of scientific support, whose role in modern conditions of formation and development of the national system of agrarian science, as well as the search for ways of its integration, becomes particularly importance. In the early 1920s Ukrainian, Western European and American agrarian scientists discovered the effectiveness of scientifically justified agricultural production taking into account soil and climatic conditions. At that time, it became an impetus to the application of the regional principle as the main way of organization of scientific support of Ukrainian agriculture in the new economic conditions. For the development of agrarian science, the organizational model of sectoral research according to the American type was used, as the most effective world example of research work organization, where the main role was played by regional research stations. For the effective organization of scientific support, in their structure there were departments for various scientific fields: field farming, horticulture, gardening, breeding, agrochemistry, entomology, phytopathology, agricultural meteorology, animal husbandry and agricultural economics, which later developed into special research institutes. In modern conditions to the regional principle in Ukraine powerful specialized National Research Centers have been formed, which have improved and expanded the sectoral research work in different soil and climatic conditions of the country: Southern, Central and Northern Steppe; insufficient, unstable and sufficient humidified of the Forest-Steppe; Polissya. At the beginning of the 21st century, Ukrainian scientists developed innovative technologies in various areas of specialization, processed the strategy of computerization of the agrarian sector, introduced economic and mathematical modeling for different levels of management of agricultural production processes and created regional information databases. Ukrainian scientists are now intensively cooperation with their foreign colleagues to develop and implement joint research programs, hold international congresses and symposia and establish international sectoral scientific organizations. It is important to solve large-scale problems, the main of which are the sustainable development of agroecosystems, ecologization and biologization of agrarian production, conservation and improvement of soil fertility and biodiversity, as well as production of ecological friendly products.
\end{abstract}

Key words: regional development, regional research stations, agrarian science, innovative technologies, computer modeling, areas of specialization, ecologization and biologization, production of ecological friendly products. 